\title{
PENGHILANGAN/PENURUNAN KADAR PHENOL PADA AIR LIMBAH DENGAN MENGGUNAKAN ENZIM PEROKSIDASE DAN KOAGULAN
}

Oleh

\section{Aida Soelaeman *)}

\begin{abstract}
:
Phenols are effectively removed by treatment with peroxidase and a cationic polymer coagulant. The coagulant precipitated enzymatic products of phenol, and reduced the in activation of peroxidase caused by reaction of products from phenol with the enzyme.
\end{abstract}

\section{PENDAHULUAN}

Dalam air limbah industri banyak kita jumpai komponen phenol, didalam komponen ini bersifat racun. Karena itu pada penelitian ini, dicoba untuk menghilangkan komponen phenol dengan cara proses enzimatik. Pada proses enzimatik ini digunakan juga koagulan sebagai additive. Adapun jenis -

enzim yang dapat digunakan adalah jenis tyrosinase dan peroksidase, sedangkan koagulan yang digunakan adalah hexamethylenediamine - epichlorohydrin polycondensates. Secara umum reaksi penghilangan phenol dalam air limbah adalah sebagai berikut :

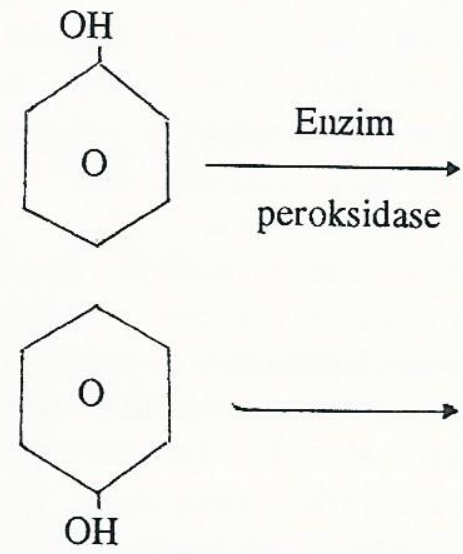<smiles>COc1ccccc1</smiles>

$$
\text { grup quinon }
$$

radikal phenoxy

\section{TUJUAN PENELITIAN}

Tujuan penelitian ini adalah untuk menge-

*) Staf Peneliti

Balai Penelitian Kimia Organik \& Fermentasi Balai Besar Industri Kimia tahui beberapa besar turunnya kadar phenol dalam air limbah yang mengandung phenol, dengan penambahan enzim peroksidase dan koagulan.

\section{TINJAUAN PUSTAKA}

Peroksidase yang berasal dari horseradish - 
(jenis tumbuhan) merupakan substrat yang spesifik dan merupakan katalis untuk mengoksidasi phenol dan amin aromatik dengan menambahkan hidrogen peroksida (PUTTER dan BECKER, 1983).

Penggunaan katalis untuk menghilangkan komponen aromatik telah dicoba KLIBANOV'S group (KLIBANOV et.al., KLIBANOV dan MORRIS, 1980). Radikal phenoxy dan amin aromatik dihasilkan dari proses reaksi oksidasi (WALSH, 179) yang akhirnya akan menghasilkan zat yang sangat reaktif (berupa polimer) yang tidak larut dalam air yang dapat dipisahkan dengan cara pengendapan yang selanjutnya dapat disaring.

KLIBANOV et.al (1983) telah berhasil membuat enzim peroksidase yang berasal dari horseradish, yang mana telah dibuktikan dalam influen yang mengandung phenol dapat dihilangkan dengan reaksi polimerisasi, dan ia telah memperlihatkan bahwa reaksi enzimatik ini sangat efektif untuk berbagai kondisi $\mathrm{pH}$, suhu dan konsentrasi dari phenol (KLIBANOV et.al, 1983). Reaksi penambahan amino group untuk membentuk quinone melalui reaksi enzimatik :

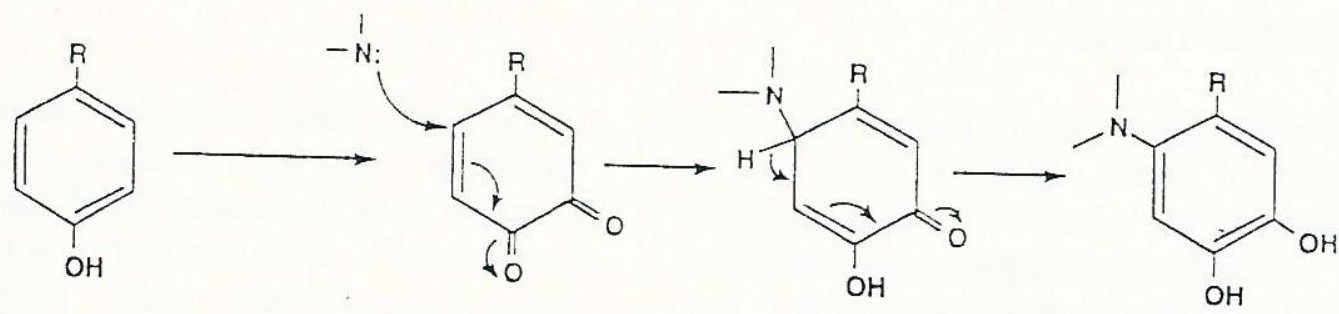

Sedangkan reaksi oksidasi phenol dengan peroksidase :

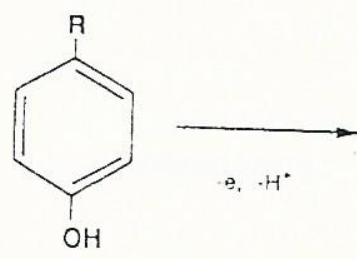<smiles>Oc1ccc(O)cc1</smiles><smiles>CC1=CC(=O)CC(I)=C1</smiles>

Peroksidase banyak terdapat pada tumbuhtumbuhan dan hewan. Pada tumbuhtumbuhan misalnya terdapat pada horseradish, nanas, pohon ara, kentang, tumbuhan polong, wortel, tembakau, ragi, jamur, bakteri dan lain-lain. Sedang pada hewan banyak terdapat pada leukosit, susu, hati, limpa, air liur, paru-paru dan lain-lain. Juga ditemukan pada cell mamalia yaitu pada cytoplasma, mitochondria, microsomes dan lysosomes. Phenol dapat diuraikan dengan proses bioenzimatik. Hasil percobaan ini merupakan indikasi bahwa pengolahan air limbah secara enzimatik dapat menggantikan cara lain sebelumnya yang biasanya menggunakan cara penyerapan penggunaan karbon aktif, ekstraksi dan oksidasi biologi. Agar supaya proses pengolahan air limbah dengan cara enzimatik berlangsung ekonomis, maka perlu mengurangi biaya pengolahan dengan cara mengurangi jumlah penggunaan peroksidase. Telah dijelaskan bahwa terjadinya enzim tidak aktif karena ter bentuknya polimer pada akhir proses dari subtrat ke enzim aktif, sehingga polimer yang terbentuk menghambat enzim untuk tidak aktif. Dengan penambahan protein atau polimer sintetis (additive), enzim yang 
terserap akan tertahan dan pada akhirnya keaktifan enzim akan berkurang secara dramatis sehingga akan mengurangi enzyme yang dibutuhkan. Additive ini menghalangi terjadinya interaksi antara enzyme dan polimer phenol. Katalis peroksidase dan additive dapat digunakan untuk menghilangkan phenol yang terkandung dalam larutan sebesar 10 - 30 gram/liter dalam air limbah.

\section{Reaksi polimerisasi Phenol Tanpa Additive}

Perubahan keaktifan dan konsentrasi enzim peroksidase selama reaksi polimerisasi tanpa penambahan additive telah dibuktikan melalui suatu penelitian $\left(5^{*}\right)$. Dibuktikan bahwa aktifitas enzim peroksidase akan menurun secara logaritma sebesar $0,1 \%$ dari keaktifan awal dan konsentrasi enzimpun akan menurun sejalan dengan keaktifan enzim. Hal ini dikarenakan enzim peroksidase dalam keadaan awal akan larut dalam reaksi campuran dan keaktifannya akan berkurang selama proses polimerisasi berlangsung. Keaktifan enzim akan berkurang, ini disebabkan karena pada keadaan awal molekul peroksidase melekat pada molekul phenol yang telah terpolimerisasi, sementara itu keaktifan enzim tertahan yang lama-kelamaan menjadi tidak aktif karena phenol yang terpolimerisasi tersebut mengurangi aktifitas enzim. Penelitian ini menunjukan bahwa peroksidase itu sendiri tidak aktif selama reaksi berlangsung karena terjadinya interaksi antara radikal phenoxy dan enzim aktif.

\section{Reaksi Polimerisasi Phenol Dengan Meng- gunakan Additive.}

Melekatnya molekul peroksidase dengan molekul phenol pada proses polimerisasi membuktikan bahwa jumlah dan aktifitas enzim peroksidase untuk mengurangi kadar phenol dalam air limbah akan berkurang, dan dari keterangan di ataspun diketahui bahwa keaktifan enzim tertahan karena enzim membentuk polimer phenol, sehingga konsentrasi phenol akan berkurang. Untuk memperlambat pembentukan enzim yang tidak aktif ini maka dipilih gelatin sebagai additive dengan maksud agar supaya dapat memperlambat pembentukan ketidak aktifan enzim tersebut, sehingga enzim peroksidase dapat menghilangkan/mengurangi kadar phenol yang terkandung dalam air limbah. Hubungan antara konsentrasi penggunaan gelatin (additive) dan efisiensi penurunan phenol dapat dilihat pada gambar berikut :

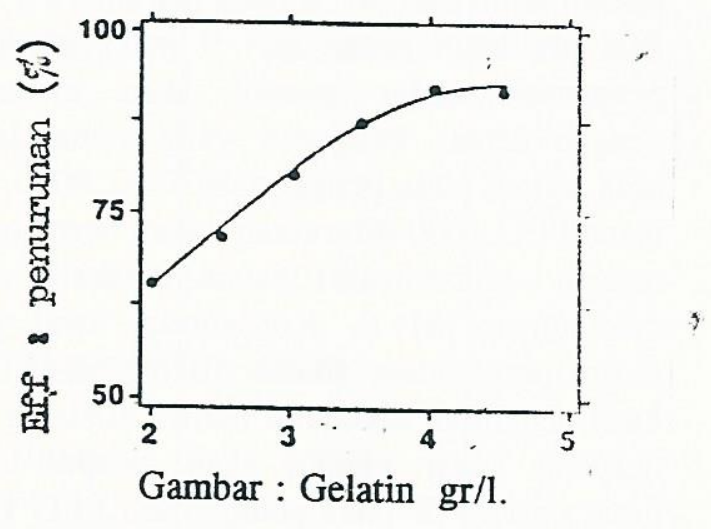

Di sini terlihat bahwa semakin besar konsentrasi gelatin yang ditambahkan kedalam pengolahan air limbah yang mengandung phenol maka akan semakin besar efisiensi penurunan kadar phenol dalam air limbah tersebut. Efisiensi penurunan digambarkan dalam bentuk prosentase penurunan kadar phenol dalam larutan. Untuk efisiensi penurunan phenol lebih dari $90 \%$ terjadi pada konsentrasi gelatin lebih dari 4 gram / liter. Menurut hasil penelitian S. Nakamoto dan N.Nachida, mereka menetapkan pada percobaannya bahwa konsentrasi enzim peroksidase yang digunakan adalah 10 milligram/liter, dengan kadar ini enzim sudah dapat menurunkan/menghilangkan phenol 
dalam air limbah,di samping itu ditambahkan nya pereaksi $\mathrm{H}_{2} \mathrm{O}_{2}$ dengan maksud sebagai pengoksid. Keaktifan enzim peroksidase akan menurun dengan adanya penambahan gelatin, dan konsentrasi protein dalam supernatan juga berlangsung menurun dengan penambahan $\mathrm{H}_{2} \mathrm{O}_{2}$, ini dikarenakan melekatnya gelatin bersama dengan terbentuknya polimer phenol. Di samping itu semua, efisiensi penurunan kadar phenol dalam air limbah tergantung pada $\mathrm{pH}$, adapun $\mathrm{pH}$ yang diharapkan adalah sekitar 5-10. Telah dibuktikan bahwa dalam campuran yang mengandung 4 gram/liter gelatin, 10 milligram/liter enzimperoksidase dan 10 gram/liter phenol, maka akan dicapai efisiensi penurunan kadar phenol lebih dari $90 \%$ pada pH antara $5-8$. Bila pH lebih besar dari 9 maka efisiensi penurunan kadar phenol akan menurun dengan cepat. Pengaruh yang sama dapat pula terjadi pada penggunaan PEG 1000 , dimana PEG 1000 dilarutkan dalam bermacammacam konsentrasi dalam reaksi yang mempunyai pH 6. Konsentrasi awal dari enzim peroksidase adalah $10 \mathrm{mg} /$ liter. Dari hasil penelitian diketahui bahwa efisiensi penurunan kadar phenol akan dicapai lebih besar dari $90 \%$ pada penggunaan PEG 1000 dengan konsentrasi gram/liter. Pada konsentrasi ini, kira-kira $30 \%$ dari PEG 1000 ditambahkan pada awal reaksi dan sisanya pada akhir reaksi dimana akan terbentuknya supernatan.

\section{BAHAN DAN METODA}

Bahan-bahan kimia yang digunakan antara lain :

- Enzim Peroksidase berasal dari Wako Pure Chemical Industries Ltd, Japan yang mempunyai spesific activity $100 \mathrm{unit} / \mathrm{mg}$.

$-\mathrm{H}_{2} \mathrm{O}_{2} 30 \%$ didapatkan dari Mitsubishi Gas Chemical Co Ltd, Japan.

- ABTS (2,2 - azino - di [3 - ethylbenzthiazoline sulfonat (6)] yang diperoleh dari Wako
Pure Chemical Industries Ltd, Japan.

Pengujian Aktifitas Enzim Peroksidase :

Aktifitas enzim peroksidase diuji dengan menggunakan ABTS sebagai substrat pada temperatur $25^{\circ} \mathrm{C}$ (Putter dan Becker, 1983). Campuran reaksi mengandung $12 \mathrm{mM}$ $\mathrm{K}_{2} \mathrm{HPO}_{4} / 88 \mathrm{mM} \mathrm{KH} \mathrm{PO}_{4}(\mathrm{pH}=6,0), 18$ $\mathrm{mM}$ ABTS dalam total volume $2,2 \mathrm{ml}$. 0,2 $\mathrm{ml} \mathrm{H}_{2} \mathrm{O}_{2} \quad 10 \mathrm{mM}$ ditambahkan langsung kedalam campuran sebelum pengujian. Konsentrasi $\mathrm{H}_{2} \mathrm{O}_{2}$ diuji pada spectrophotometer dengan panjang gelombang $240 \mathrm{~nm}$, dan setelah penambahan $0,05 \mathrm{ml}$ sample (contoh), panjang gelombang segera diubah menjadi $405 \mathrm{~nm}$.

Analisa Chromatographi dan Spektroskopi :

Hilangnya phenol dapat dimonitor dengan menggunakan High Performance Liquid Chromatographic (HPLC), merk Jasco PU980 (Japan Spectroscopic Tokyo, Japan), UV-detector (Jasco UV-970) dan integrator (Jasco 807 - IT). Reverse phase column, Cosmosil $\mathrm{C}_{18}(5 \mathrm{u}, 4,6 \mathrm{~mm}, 1 \mathrm{~d} \times 25 \mathrm{~cm}$, Narakaitesque, Kyoto Japan). Kecepatan aliran adalah $1,0 \mathrm{ml} / \mathrm{menit}$ dengan perbandingan methanol dan air adalah $1: 1$.

\section{HASIL DAN PEMBAHASAN}

Penghilangan phenol dalam air limbah dapat dihilangkan/diturunkan kadarnya dengan menggunakan enzim peroksidase dan koagulan, dimana penurunan/penghilangan kadar phenol dalam air limbah tersebut sangat tergantung kepada jumlah enzim peroksidase dan koagulan yang kita gunakan.

\section{Penurunan/Penghilangan Kadar Phenol.}

Sebelum mengetahui berapa besar penurunan kadar phenol, komposisi dari larutan asal adalah sebagai berikut : 
phenol

$: 1 \mathrm{mM}$

Enzim peroksidase : bervariasi mulai dari 0,5 $\mathrm{u} / \mathrm{ml}-1 \mathrm{u} / \mathrm{ml}$.

$\mathrm{H}_{2} \mathrm{O}_{2} \quad: 1,2 \mathrm{mM}$.

Kemudian larutan ini diaduk selama 15 menit, setelah terjadi reaksi, larutan tersebut diukur kadar phenolnya dengan menggunakan HPLC. Penghilangan/penurunan kadar phenol dengan menggunakan enzim peroksidase dan koagulan dapat dilihat pada tabel 1 dan gambar 1 (Penghilangan/penurunan kadar phenol dengan menggunakan enzim peroksidase).

Tabel 1 : Penghilangan/penurunan kadar phenol dengan menggunakan enzim peroksidase

\begin{tabular}{|l|c|c|c|}
\hline Untuk Larutan & Enzim ( $/ \mathrm{ml})$ & $\%$ Penurunan & $\begin{array}{c}\text { Absorbance } \\
400 \mathrm{~nm}\end{array}$ \\
\hline $\begin{array}{l}\text { Coklat, tidak ada } \\
\text { endapan. }\end{array}$ & 0,05 & 10,5 & 0,220 \\
Bening, ada endapan & 0,1 & 22,0 & 0,113 \\
Bening, ada endapan & 0,2 & 56,4 & 0,100 \\
Bening, ada endapan & 0,5 & 91,3 & 0,227 \\
Bening, ada endapan & 1,0 & 100,0 & 1,230 \\
\hline
\end{tabular}

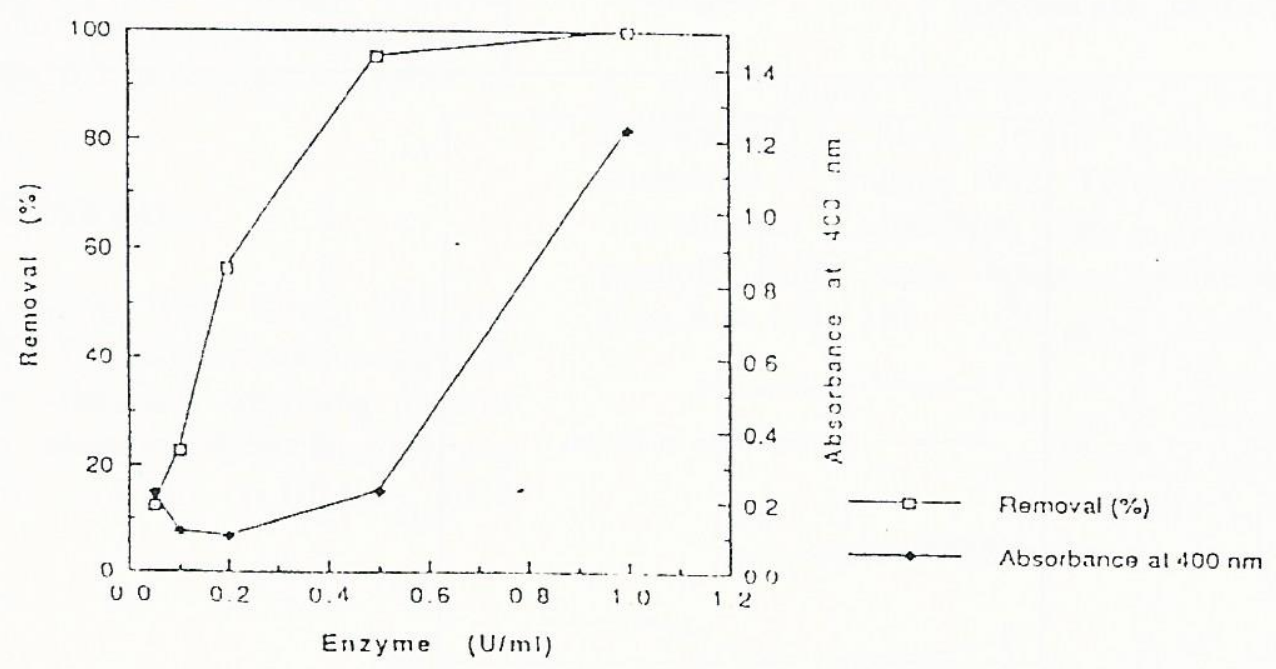

Gambar 1 : Penghilangan/Penurunan kadar phenol dengan menggunakan enzim peroksidase 


\section{Gambar 1 :}

Warna larutan diukur pada panjang gelombang $400 \mathrm{~nm}$. Penurunan kadar phenol dan peningkatan warna pada larutan terjadi pada kadar enzim peroksidase diatas $0,5 \mathrm{u} / \mathrm{ml}$. Pada kadar enzim peroksidase yang paling besar yaitu $1 \mathrm{u} / \mathrm{ml}$, prosentase penghilangan phenol mencapai $100 \%$. Sedangkan warna larutan akan semakin tampak dikarenakan terbentuknya produk lain berupa endapan. Untuk mengetahui sejauhmana kadar phenol dapat dihilangkan/diturunkan dengan menggunakan enzim peroksidase dan koagulan dapat dilihat pada tabel 2 dan gambar 2 (Penghilangan/penurunan kadar phenol dengan menggunakan enzim dan koagulan). Adapun komposisi larutan asal adalah sebagai berikut :

$$
\begin{aligned}
\text { Koagulan } & =\text { bervariasi dari } 2-50 \mathrm{mg} / 1 \\
\text { Enzim } & =0,2 \mathrm{u} / \mathrm{ml} \\
. \mathrm{H} 2 \mathrm{O} 2 & =1,2 \mathrm{mM} \\
\text { Phenol } & =1 \mathrm{mM}
\end{aligned}
$$

Tabel 2 : Penghilangan/penurunan kadar phenol dengan menggunakan enzim dan koagulan

\begin{tabular}{|c|c|c|c|}
\hline Bentuk Larutan & $\begin{array}{c}\text { Koagulan } \\
(\mathrm{mg} / \mathrm{l})\end{array}$ & $\%$ Penurunan & $\begin{array}{c}\text { Absorbance } \\
400 \mathrm{~nm}\end{array}$ \\
\hline Berwarna, ada endapan & 2 & 81,62 & 0,028 \\
Berwarna, ada endapan & 5 & 30,34 & 0,010 \\
Berwarna, ada endapan & 10 & 25,13 & 0,027 \\
Berwarna, ada endapan & 20 & 100,0 & 0,112 \\
Berwarna, ada endapan & 50 & 100,0 & 0,100 \\
\hline
\end{tabular}

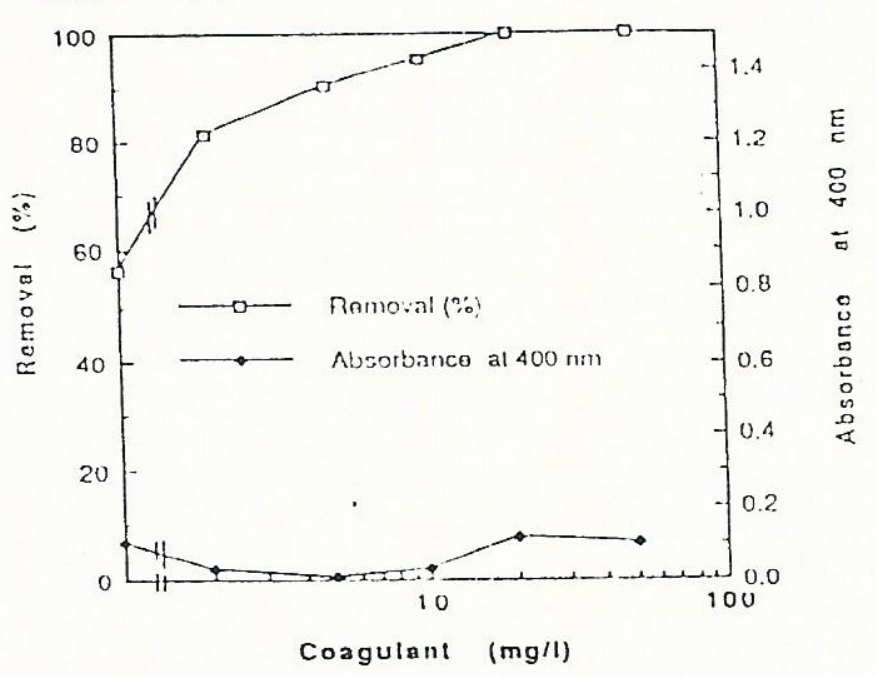

Gambar 2 : Penghilangan/penurunan kadar phenol dengan menggunakan enzim dan koagulan 
gambar 2 :

Menggambarkan penghilangan kadar phenol dan penghilangan warna dengan penambahan koagulan. Pada konsentrasi koagulan $2 \mathrm{mg} / \mathrm{l}$, prosentase penghilangan phenol dicapai sebesar $81 \%$. Untuk konsentrasi koagulan yang lebih besar, prosentase penghilangan kadar phenol lebih besar, juga warna dari larutan akan menurun, karena koagulan mencegah terjadinya peroksidase yang tidak aktif. Penghilangan kadar phenol mencapai $100 \%$, pada penggunaan koagulan sebanyak $20 \mathrm{mg} / \mathrm{l}$. Pada reaksi ini banyak terbentuk endapan sehingga dapat dipisahkan dengan cara penyaringan.

\section{KESIMPULAN}

Dalam air limbah yang mengandung phenol, dapat kita hilangkan/diturunkan kadarnya dengan menggunakan enzim peroksidase dan koagulan. Untuk menghilangkan/menurunkan kadar phenol dimana tidak digunakan koagulan, hanya menggunakan enzim maka terbukti bahwa phenol dapat dihilangkan 100 $\%$ dalam air limbah tersebut dengan menggunakan enzim $1 \mathrm{u} / \mathrm{ml}$. Dan apabila dalam proses pengolahan tersebut digunakan koagulan maka kadar phenol dapat dihilangkan $100 \%$ dari air limbah dengan menggunakan enzim $0,2 \mathrm{u} / \mathrm{ml}$ dan koagulan 20 $\mathrm{mg} / \mathrm{l}$.

\section{DAFTAR PUSTAKA}

1. Gregory F.Payne, Wei - Qiang Sun, and Afshin Sohrabi, Tyrosinase reaktion/chitosan adsorption for selectively removing phenols from aqueous mixtures. Biotechnology ang Bioengineering, vol 40, p.1011 - 1018 (1992).
2. Klibanov A.M. and Morris E.D. (1980) Horseradish peroxidase for the removal of carcinogenic aromatic amines from water. Enzyme Microb. Technol. 3,119 - 122.

3. Putter J and Becker R (1983). Peroxidase in methods of enzymatic analysis (edited by Bergmeyer J and Gra BLM). 3 rd edition, Vol. 3.

4. Shinji Wada, Hiroyasu Ichikawa, and Kenji Tatsumi, 1993, Removal of phenol from waste water by soluble and immobilized tyrosinase, Biotechnology and Bioengineering, vol.42, p. 854 - 858 (1983).

5. S. Nakamoto and N. Machida, 1991. Phenol removal from aqueous solution by peroxidase - catalyzed reaction using additives. wat.res vol 26 No.1, p. $49-54$, 1992.

6. Tasumi, K, Ichikawa, H, Wada.S, 1991. Dephenolization of waste water catalyzed by soluble and immobilized tyrosinase. Proc. Asian waterqual.

7. Walsh (1979) Enzymatic reaction mechanisms, p. 488 - 490. Freeman, San Fransisco.

8. Wei - Qiang Sun, Gregory F. Payne, Monica S.G.L. Moas, Jenifer H.Chu, and Kimberlee K, wallace 1992, Tyrosinasereaction/chitosan adsorption for removing phenols from waste water. Biotechnol Prog. $8=179-187$. 